\begin{tabular}{|l|l|l|l|l|l|}
\hline J. Tek. Ling & Vol. 12 & No. 1 & Hal. 93 - 101 & Jakarta, Januari 2011 & ISSN 1441-318X \\
\hline
\end{tabular}

\title{
PREDIKSI PARAMETER-PARAMETER BIOFISIK TANAMAN PADI DARI DATA GROUNDSPECTROMETER DAN HYPERSPECTRAL PESAWAT TERBANG DENGAN MENGGUNAKAN TEKNIK PARTIAL LEAST SQUARE REGRESSION (PLSR) DAN NORMALIZED DIFFERENCE SPECTRAL INDEX (NDSI)
}

\author{
Arief Darmawan ${ }^{1,2}$, Teguh Hariyanto', Bangun Muljo Sukojo1, Muhamad Sadly² \\ ${ }^{1}$ Program Studi Pasca Sarjana Tenik Sipil Insitut Teknologi Sepuluh November Surabaya, \\ Kampus ITS Sukolilo, Surabaya 60111 \\ 2Pusat Teknologi Inventarisasi Sumberdaya Alam Badan Pengkajian dan Penerapan Teknologi, \\ JI. MH. Thamrin no 8 Jakarta 10340, Email: ariefd@webmail.bppt.go.id
}

\begin{abstract}
Paddy rice canopy hyperspectral was measured by using ground-based spectroradiometer and HyMap sensor onboard an airplane from $350 \mathrm{~nm}$ up to $2500 \mathrm{~nm}$ in the same time that covered various growth stages. Coinciding with hyperspectral measurement, biophysical parameters such as leaf area index (LAI), SPAD value were measured on ground during the airplane passed over area of interest (AOI). Rice yield was measured at the time of final harvesting by random selected yield (ubinan method) for each sampling area. In finding the best correlation among canopy hyperspectral reflectance with crop development, optimal individual waveband explored with involving all possible waveband combinations to obtain the best fitted two-pair waveband related to crop biophysical parameters. Normalized Difference Spectral Index (NDSI) was applied from spectral transformations (obtained from optimal waveband selected by exploring all possible waveband) to improve sensitivity analysis on plant. Canopy hyperspectral provided information about plant, soil and water background when plant canopy don't completely cover soil surface yet. The present study was directed to examine spectral indices and establish the relationships between biophysical parameters of rice by using partial least square regression (PLSR) technique.
\end{abstract}

Key words: Hyperspectral, NDSI, spectral indices, PLSR, ground-based spectroradiometer

\section{Pendahuluan}

\subsection{Latar Belakang}

Teknologi hyperspektral penginderaan jauh merupakan pengembangan dari teknologi multispektral yang telah diterapkan pada berbagai aplikasi peneltian termasuk dalam bidang pertanian. Dengan memiliki ratusan bahkan ribuan kanal yang sempit (narrow-band), data yang dihasilkan dapat disajikan dalam bentuk informasi spektral yang kontinu dan detil pada setiap objek yang diamati (Mutanga and Skidmore, 2004 
dalam ${ }^{1)}$.. Karena kemampuannya dalam menyediakan analisis informasi yang lebih detil, dimensi data yang dihasilkan akan sangat besar dan ini merupakan tantangan baru tidak hanya pada teknik pengolahan data tapi juga pada penyimpanan dan pemidahan (transport) datanya ${ }^{2}$. Pengukuran spektral tanaman padi dan hubungannya dengan karakteristik karakteristik spektral dengan parameter-parameter biofisik tanaman seperti klorofil (SPAD), indeks luas daun (LAI) dan panen merupakan suatu yang akan dibahas dalam penelitian ini. Penelitianpenelitian terdahulu telah mengembangkan beberapa indeks spektral seperti Ratio Spectral Index (RSI), Normalized Difference Spectral Index (NDSI), Soil Adjusted Spectral Index (SASI), dan Renormalized Difference Spectral Index (RDSI) dari transformasi spektral dari beberapa panjang gelombang untuk meningkatkan pengukuran secara radiometrik pada suatu vegetasi dan untuk memonitor serta mengevaluasi perkembangan dari vegetasi yang diamati. Penentuan indeks-indeks spektral ini berdasarkan pada 2 hal yaitu tingginya nilai penyerapan dari panjang gelombang tampak (visible) radiasi matahari oleh pigmen tanaman dan tingginya nilai hamburan (scattering) gelombang infra merah (Infrared) oleh lapisan mesophyll daun. Secara teori dapat dikatakan bahwa penggunaan kombinasi nilai spektral reflektan dari dua atau lebih pada panjang gelombang tertentu dapat meningkatkan tingkat kepekaan (sensitivity) tehadap vegetasi daripada hanya menggunakan satu nilai spektral pada panjang gelombang tertentu ${ }^{3,4)}$. Beberapa studi menunjukkan bahwa hubungan antara karakteristik reflektan dengan beberapa atribut vegetasi melalui analisis regresi dari data hyperspektral akan memberikan hasil yang lebih baik.

Metode Partial Least Square Regression (PLSR) yang diperkenalkan oleh Wold sekitar tahun 1960-an untuk econometric adalah salah satu metode regresi yang kemudian menjadi suatu teknik analisis regresi yang sangat diandalkan dan populer dalam berbagai aplikasi keilmuan dan penelitian ${ }^{5,6)}$. Sekitar tahun 1970-an, banyak metodemetode percobaan yang menggunakan PLSR sebagai alat untuk menganalisa data-data kimia ${ }^{7,8}$. PLSR adalah suatu teknik regresi peubah banyak yang mudah digunakan dalam mencari hubungan antara beberapa peubah. PLSR bekerja secara iterative untuk menemukan suatu hubungan antara data masukan pada ruang $X$ multi dimensi dan keluarannya yaitu variance multi dimensi dari ruang Y. Sama seperti PCA, hasilnya akan mengurangi jumlah dimensi data melalui identifikasi latent atau peubah tersembunyi (hidden) yang berhubungan dengan vector ciri (eigenvector) di dalam suatu nilai ciri (eigenvalue). Dengan memilih beberapa komponen dalam tiap langkah pemrosesan, dan setelah pemrosesan beberapa komponen pertama, teknik ini dapat menemukan model yang optimalnya (Helland 1988, Martens dan Naes 1989 dalam 9). Dapat dikatakan bahwa teknik ini adalah suatu proses lanjutan dari analisis regresi linier peubah banyak dimana pengaruh dari kombinasi linier pada beberapa predictor terhadap peubah respon kemudian akan di analisa kembali.

\subsection{Lokasi Penelitian}

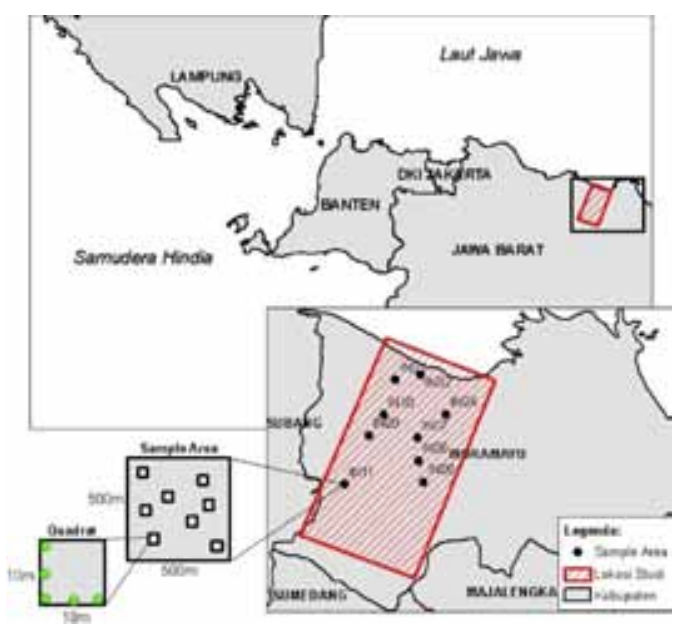

Gambar 1. Lokasi penelitian 


\subsection{Tujuan}

Penelitian ini bertujuan melakukan analisis regresi multivariat dengan metode PLSR pada beberapa parameter biofisik tanaman terhadap nilai spektral reflektansi dari data Hiperspektral. Kemudian menentukan kombinasi kanal-kanal optimal dari data hiperspektral dan ground spectroradiometer untuk perhitungan NDSI.

\section{Metodologi}

\subsection{Pengukuran spektral tanaman padi}

Perekaman data spektral irradiance (in situ) pada rentang panjang gelombang 350$2500 \mathrm{~nm}$ dilakukan dengan menggunakan alat groundspectrometer (FieldSpect ASD) interval $1 \mathrm{~nm}$ dengan ketinggian sensor 10 $\mathrm{cm}$ (FS10) dan $50 \mathrm{~cm}$ (FS50) dari atas kanopi serta perekaman data hyperspectral wahana pesawat dengan sensor Hymap yang memiliki 126 kanal pada rentang panjang gelombang $450 \mathrm{~nm}-2480 \mathrm{~nm}$, dilakukan di Kabupaten Indramayu. Sedangkan untuk data LAI dan SPAD, pengukuran dilakukan pada 9 area sampling yang tiap sampling berukuran $500 \mathrm{~m} \times 500 \mathrm{~m}$ yang terdiri dari 10 'quadrat' yang diseleksi dengan ukuran area $10 \mathrm{~m} \times 10 \mathrm{~m}$. Pengukuran spektral dilakukan dengan 5 pengulangan pada tiap quadrat untuk meminimalkan pengaruh dari perubahan cuaca.

\subsection{Partial Least-Square Regression (PLSR)}

PLSR dapat diilustrasikan seperti skema berikut ini:

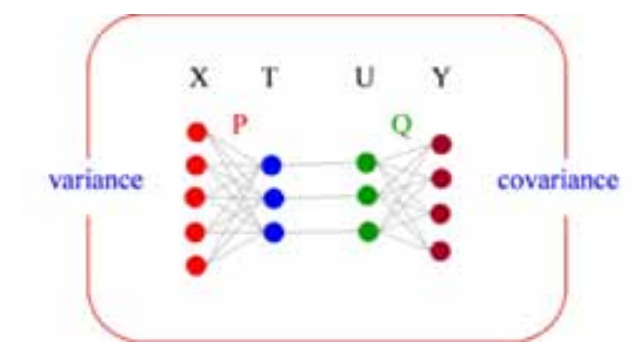

dimana:

Y: prediktor

$\mathrm{X}$ : peubah

$P$ :loading matrix dari masukan peubah laten

Q: loading matrix dari keluaran peubah laten

$\mathrm{U}:$ PLS weight matrix

$\mathrm{T}$ : score matrix dari masukan peubah laten

Dari skema di atas terlihat ada 2 blok terpisah yaitu blok $X$ dan $Y$ serta bagaimana hubungan dalam antara kedua blok tersebut. Hubungan luar untuk blok $X$ yaitu, $X=T P^{\prime}+$ $E$ dan $Y=U Q^{\prime}+F$. Penyederhanaan model akan meliputi suatu model regresi antara skor untuk $X$ dan $Y$ seperti yang terlihat pada skema di bawah ini:

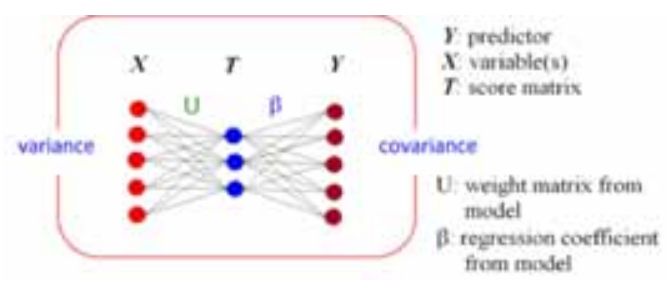

Akhirnya, korelasi yang tertinggi antara reflektan hiperspektral tajuk dengan parameter tanaman dapat diestimasi dengan menggunakan persamaan berikut ini:

$$
\widehat{Y}=\bar{Y}+(Z-\bar{X}) W_{g} \widehat{C}
$$

dimana:

$\bar{X} \quad$ : Nilai tengah matrik sample yang digunakan di dalam model

$W_{g}$ : Weight matrik yang diturunkan dari algoritma PLS1

$\hat{C}$ : Koefisien regresi yang diturunkan dari algoritma PLS1

$\bar{Y} \quad$ : Nilai tengah parameter biofisik yang digunakan di dalam model.

$\hat{Y}$ : Prediktor

$Z$ : Matrik spektral matrix yang akan digunakan dalam prediksi 
Koefisien determinan $\left(\mathrm{R}^{2}\right)$ dan Root Mean Square Error (RMSE) dapat dihitung dengan menggunakan persamaan di bawah ini:

$$
\begin{gathered}
R^{2}=1-\frac{\sum_{i=1}^{n}\left(Y_{i}-Y_{p}\right)^{2}}{\sum_{i=1}^{n}\left(Y_{i}-Y_{m}\right)^{2}} \\
R M S E=\sqrt{\frac{\sum_{i=1}^{n}\left(Y_{i}-Y_{p}\right)^{2}}{n}}
\end{gathered}
$$

dengan Yi adalah prediksi peubah tanaman dari model PLSR, Yp merupakan karakteristik tanaman yang diukur untuk seluruh set data dan Ym adalah nilai rata-rata dari Yp.

Analisa data dilakukan dengan menggunakan data fieldspec dan Hymap dari survey lapang (jumlah data adalah 104). Analisis PLSR ditampilkan dalam reflektan tunggal untuk memprediksi LAI, nilai SPAD dan panen. Untuk menentukan jumlah optimal dari peubah laten pada model PLSR, RMSE dihitung dan selanjutnya nilai terendahlah yang digunakan sebagai jumlah dari peubah laten ${ }^{6}$.

\subsection{Normalized Difference Spectral Index (NDSI)}

Untuk menghilangkan kerancuan dengan indeks vegetasi Normalize Different Vegetation Index (NDVI), dalam penelitian ini kami menggunakan indeks vegetasi Normalized Difference Spectral Index (NDSI). NDSI diperoleh dari persamaan berikut ini:

dimana :

$$
N D S I=\frac{\lambda_{2}-\lambda_{1}}{\lambda_{2}+\lambda_{1}}
$$

$\mathrm{S}_{\mathrm{NDSI}}$ adalah Normalized Difference Spectral Index dan $\lambda_{1}, \lambda_{2}\left(\lambda_{1}<\lambda_{2}\right)$ adalah pada suatu panjang gelombang 1,2 .

\subsection{Pengukuran klorofil dengan SPAD 502}

Teknik pengukuran klorofil pada waktu survei lapangan dilakukan sebagai berikut:

- Dalam satu rumpun pengukuran dilakukan tiga kali dan dalam satu kuadrat ada 5 rumpun yang diukur.

- Hitung nilai klorofil rata-rata untuk setiap kuadrat.

\subsection{Pengukuran Indeks Luas Daun (LAI)}

Pengukuran LAI pada waktu survei menggunakan metode non-destuktif dengan alat LI-COR LAI-2000 yang dibuat oleh LiCor inc., Lincoln, NE. Jumlah daun dalam kanopi merupakan suatu faktor untuk menentukan berapa banyak cahaya yang dapat diterima oleh kanopi yang merupakan pengatur dalam laju fotosintesis. Prinsip kerja metode non-destruktif yaitu dengan melakukan pengukuran fraksi cahaya datang yang lewat melalui kanopi. Asumsi yang digunakan adalah bagaimana distribusi daun di dalam kanopi kemudian menghitung jumlah dan ukuran gap. Dari kedua informasi ini selanjutnya dapat digunakan untuk menghitung LAI. Cara kerja dari metode inilah yang kemudian diadopsi oleh alat-alat pengukur LAI seperti LI-COR LAI-2000.

\subsection{Data panen (yield)}

Data ubinan padi diukur pada waktu panen tiba untuk tiap area sampling. Pengukuran ini dilakukan oleh petugas yang ditunjuk dengan pengawasan oleh Mantri Tani dari Dinas Pertanian setempat.

\section{Hasil dan Pembahasan}

\subsection{Analisis PLSR terhadap LAI, SPAD dan panen.}

Tabel 1a, 1b, 1c menunjukkan hasil regresi PLSR antara spektral dengan parameter-parameter biofisik LAI, SPAD 
dan panen. Di dalam PLSR seluruh panjang gelombang dilibatkan dalam model kemudian hubungannya terhadap parameter-parameter biofisik tersebut diubah kedalam variabel laten. Nilai koefisien determinasi, $\mathrm{R}^{2}$ model yang diperoleh dari hasil perhitungan merupakan gambaran seberapa dekat hubungan antara nilai spektral dari data FieldSpec dengan parameter-parameter biofisik tersebut. Sedangkan nilai $\mathrm{R}^{2}$ tes adalah model regresi yang diperoleh dari data FieldSpec kemudian di uji (dites) dengan data Hymap. Nilai $R^{2}$ tes untuk SPAD dan panen menunjukkan nilai yang jauh lebih rendah dari $R^{2}$ model. Hal ini kemungkinan disebabkan oleh beberapa hal:

1. Data pengukuran SPAD dan panen merupakan data titik (point) sedangkan data LAI merupakan data spasial karena pengukurannya melalui perekaman fraksi cahaya yang diterima sensor pada suatu area sampling.

2. Untuk $\mathrm{R}^{2}$ tes terhadap data panen menunjukkan nilai yang sangat kecil. Hal ini kemungkinan disebakan oleh kesalahan pengukuran hasil produksi dilapangan sebab pengukuran hasil hanya mencakup satu quadrat (10 $\mathrm{m} \times 10 \mathrm{~m}$ ) yang kemudian nilainya dikonversi ke dalam produksi per hektar. Sehingga jika terjadi kesalahan pada pengukuran quadrat maka akan terjadi bias pada nilai produksi perhektarnya. Selain itu, data panen yang diperoleh jumlahnya sangat sedikit sekali dibanding dengan data spektral yang ada.
3. Data spektral yang diperoleh dari perekaman dengan alat FieldSpec merupakan data titik sedangkan data HyMap merupakan data spasial. Dalam perekaman data Hymap tidak hanya spektral objek yang terekam juga spektralspektral dari objek-objek di sekitarnya sehingga diperlukan proses proses pemurnian spektral objek lebih lanjut.

\section{Indeks Luas Daun (LAI)}

Table 1a.

\begin{tabular}{|r|c|r|r|r|}
\hline Model & Height & LV & \multicolumn{1}{c|}{$\begin{array}{c}\mathrm{R}^{\wedge} 2 \\
\text { Model }\end{array}$} & $\mathrm{R}^{\wedge} 2$ Test \\
\hline PLSR & FS10-HM & 12 & 0.965 & 0.906 \\
\hline & FS50-HM & 8 & 0.959 & 0.908 \\
\hline
\end{tabular}

\section{SPAD}

Table $1 \mathrm{~b}$.

\begin{tabular}{|c|c|r|r|r|}
\hline Model & Height & LV & $\begin{array}{r}\mathrm{R}^{\wedge} 2 \\
\text { Model }\end{array}$ & $\mathrm{R}^{\wedge} 2$ Test \\
\hline PLSR & FS10-HM & 15 & 0.83 & 0.496 \\
\hline & FS50-HM & 16 & 0.82 & 0.462 \\
\hline
\end{tabular}

\section{Panen (Yield)}

Table 1c.

\begin{tabular}{|l|l|l|l|l|}
\hline Model & Height & LV & $\begin{array}{r}\mathrm{R}^{\wedge} 2 \\
\text { Model }\end{array}$ & $\mathrm{R}^{\wedge} 2$ Test \\
\hline PLSR & FS10-HM & 11 & 0.864 & 0.147 \\
\hline & FS50-HM & 14 & 0.885 & 0.147 \\
\hline
\end{tabular}

Tabel 1a, 1b, 1c. Koefisien Determinasi (R2 model), jumlah latent variable (LV), koefisien determinasi validasi silang terhadap data HyMap (R2 test) untuk LAI, SPAD and Yield. 

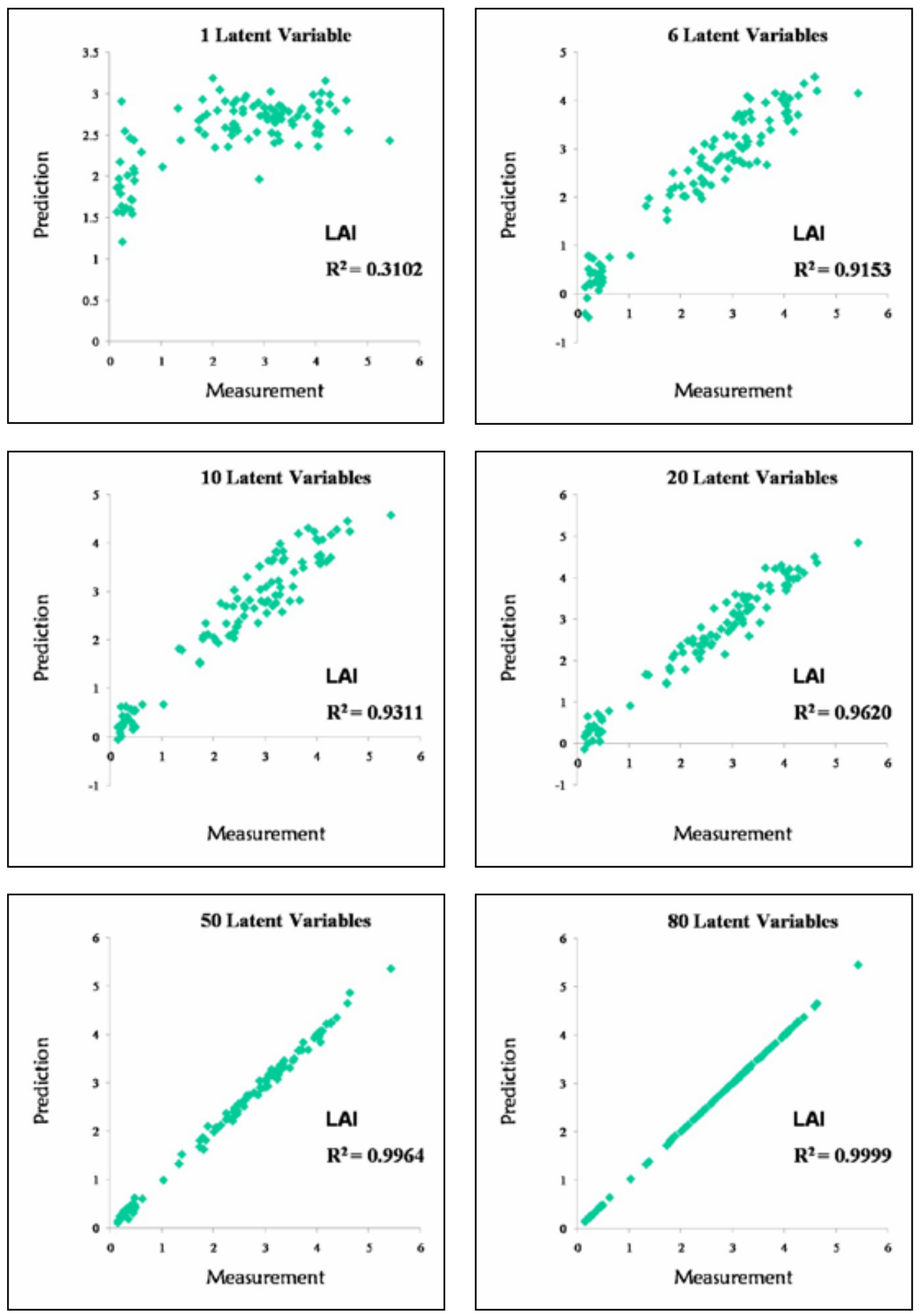


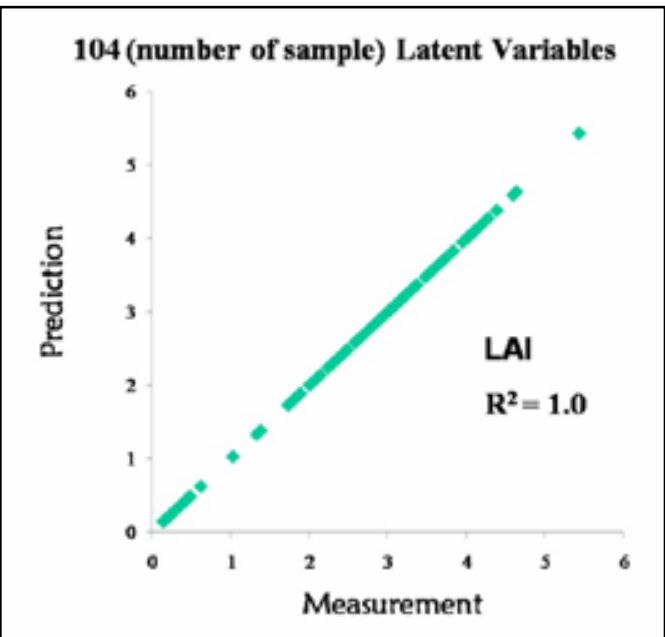

Gambar. 2. Perubahan determinasi (koefisien determinasi, $\mathrm{R}^{2}$ ) dari data LAI terhadap jumlah variabel laten (NLV).

\subsection{Analisis NDSI terhadap LAI, SPAD dan panen.}

3a.

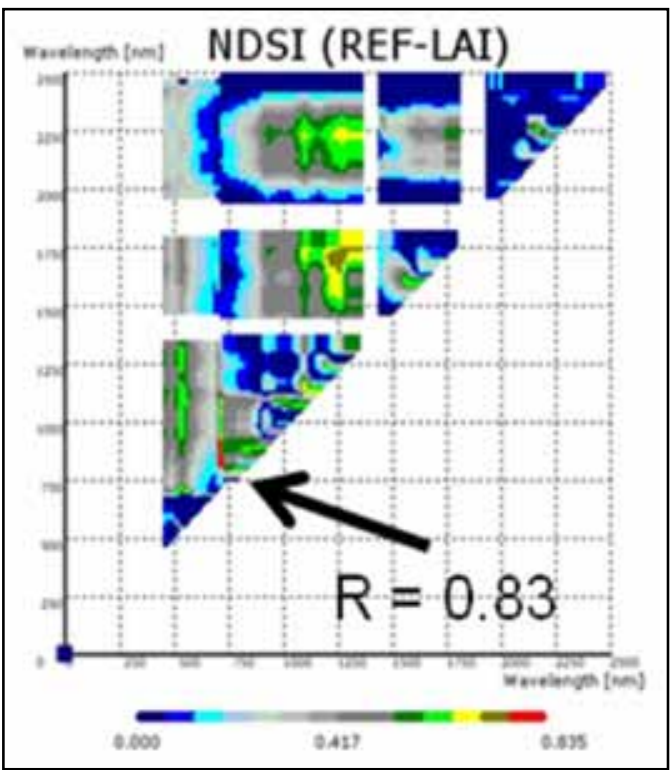

Korelasi antara indeks NDSI terhadap LAI terlihat cukup signifikan yaitu 0.83 dengan kombinasi pasangan kanal merah (red) di 700 $\mathrm{nm}-750$ dan kanal inframerah dekat (NIR)
$3 b$.

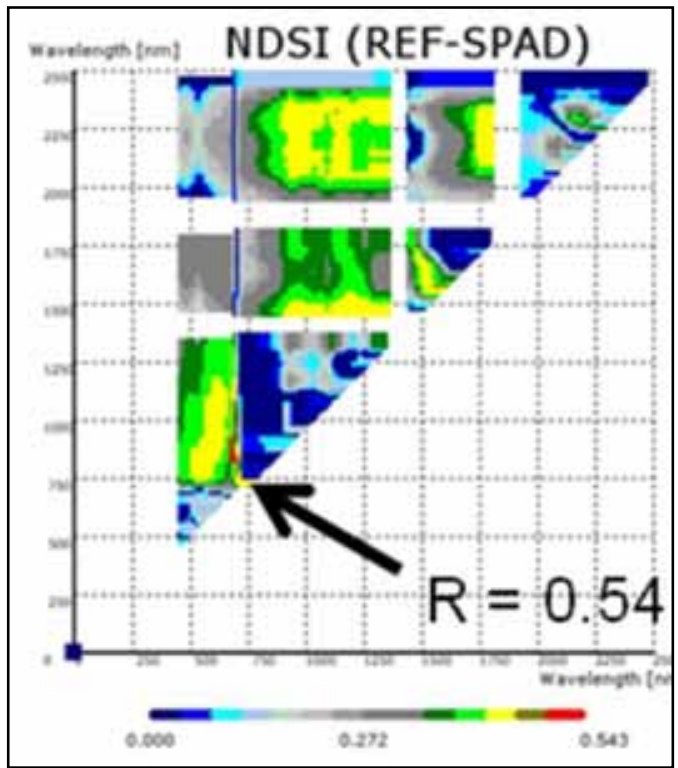

3c.

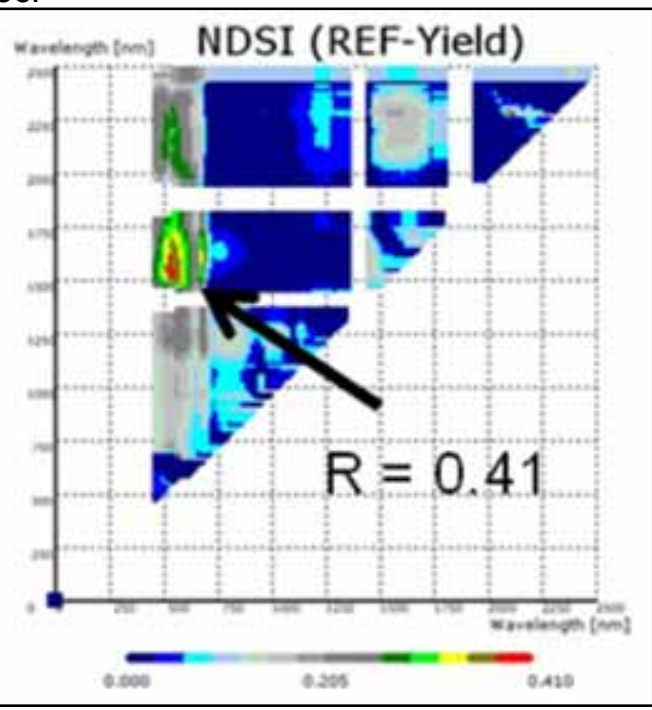

Gambar. 3a, 3b, 3c. Plot distribusi koefisien determinasi (R2) terhadap seluruh panjang gelombang. Nilai R2 diperoleh dari regresi linear antara LAI, SPAD dan panen yang terukur terhadap indeks NDSI.

di $890 \mathrm{~nm}-910 \mathrm{~nm}$. Dengan tingkat akurasi tersebut, indeks NDSI dapat digunakan untuk memprediksi LAI. Untuk korelasi antara indeks NDSI dengan klorofil (SPAD) menunjukkan nilai 
korelasi yang tidak begitu signifikan yaitu 0.54 dengan kombinasi pasangan kanal yaitu 720 nm untuk kanal merah dan 850 - 900 nm untuk kanal NIR. Dengan demikian akurasi prediksi SPAD melalui indeks NDSI kurang begitu baik. Berdasarkan teori, seharusnya indeks NDSI memiliki korelasi yang tinggi dengan nilai klorofil karena kandungan klorofil memiliki reflektansi tinggi pada regim kanal merah $(700 \mathrm{~nm}-750$ $\mathrm{nm}$ ) dan regim kanal biru (kanal biru tidak digunakan karena nilai spektralnya tumpang tindih dengan penyerapan oleh carotenoids) dan indeks NDSI pun memiliki nilai optimum di kanal merah. Hal yang mungkin menyebabkan mengapa nilai korelasi antara indeks NDSI dengan SPAD rendah adalah pada metode pengukuran klorofil itu sendiri. Pengukuran klorofil dalam penelilitian ini menggunakan SPAD-502 (Minolta Corporation, New Jersey, USA). Bagaimanapun, pengukuran klorofil dengan SPAD-502 meter menghasilkan data yang berubah-ubah (arbitrary) dibanding dengan pengukuran klorofil tiap daun di laboratorium. Hasil regresi indeks NDSI dengan nilai panen menunjukkan nilai yang yang rendah yaitu 0.41 pada pasangan kanal merah di $550 \mathrm{~nm}$ dan kanal Infra merah dekat di $1300 \mathrm{~nm}$. Seperti yang telah dijelaskan pada 3.1 bahwa kesalahan utamanya terletak pada pengukuran produksi tiap kuadratnya. Selain itu, antara besar kecilnya panen dengan nilai NDSI tidak memiliki keterkaitan secara langsung sebab besar kecilnya produksi yang paling mempengaruhi adalah nilai kecukupan nutrisi dalam hal ini pupuk dan jenis varietas. Sedangkan untuk indeks NDSI hanya bisa menjelaskan tentang fase-fase pertumbuhan pada tanaman. Jika tumbuhan telah mencapai pada fase puncak vegetasi maka indeks NDSI-nya akan mencapai nilai maksimum. Nilai indeks NDSI untuk vegetasi ini berkisar antara 0 dan 1.

\section{KESIMPULAN}

Beberapa kesimupulan yang diperoleh dari penelitian ini adalah sebagai berikut:

1. Metode PLSR dapat meningkatkan kemampuan prediksi dibanding dengan menggunakan indeks NDSI yang terlihat pada meningkatnya nilai R2 dan turunnya nilai RMSE dan NLV.

2. Indeks NDSI dapat digunakan untuk memprediksi LAI melalui penggunaan kombinasi pasangan kanal merah (red) di $700 \mathrm{~nm}-750$ dan kanal inframerah dekat (NIR) di $890 \mathrm{~nm}-910 \mathrm{~nm}$.

3. Untuk korelasi antara indeks NDSI dengan klorofil (SPAD) dan panen menunjukkan nilai korelasi yang tidak begitu signifikan yaitu 0.54 dan 0.41 . Peluang untuk menggunakan indeks NDSI ini dalam mengestimasi nilai klorofil masih besar asalkan data klorofil yang digunakan berasal dari pengukuran laboratorium. Penggunaan indeks NDSI dalam pendugaan panen tidak direkomendasikan hal ini terlihat dari nilai koefisien (R2) yang kecil.

\section{DAFTAR PUSTAKA}

1. Evri, M. Tsuyoshi Akiyama dan Kensuke Kawamura (2008). Optimal visible and near-infrared waveband used in hyperspectral indices to predict crop variables of rice. J. JASS, 24(1).

2. Jimenez, L. O. and Landgrebe, D. A. (1999). Hyperspectral Data Analysis And Supervised Feature Reduction Via Projection Pursuit IEEE Transactions On Geoscience And Remote Sensing. 37: 2653 - 2667.

3. Evri, M. Tsuyoshi Akiyama dan Kensuke Kawamura (2008). Coupling hyperspectral data with principle component regression (PCR) and partial least square regression (PLSR) to improve prediction accuracy of rice crop variables. J. JASS, 24(1).

4. Chwen-Ming Yang dan Rong-Kuen Chen (2004). Modelling Rice Growth with Hyperspectral Reflectance Data. Crop Science 44:1283-1290.

5. Carrascal, L.M, Ismael Galvan dan Oscar Goldo (2009). Partial least 
squares regression as an alternative to current regression methods used in ecology. Oikos 118, 681-690.

6. N. Yatawara (1996). Multivariate Process Monitoring with Partial Least Squares Regression: A case study. IIQP Research report RR-96-09.

7. S. Engelen, M. Hubert, K. Vanden Branden, dan S. Verboven (September 20, 2003). Robust PCR and Robust PLSR: a comparative study. Mathematics Subject Classification. 62F35; 62H20; $92 \mathrm{E} 99$.
8. Bjørn-Helge Mevik dan Henrik René Cederkvist (2004). Mean squared error of prediction (MSEP) estimates for principal component regression (PCR) and partial least squares regression (PLSR). Journal of Chemometrics, Volume 18, Issue 9, pages 422-429.

9. Gaston Sanchez (2009). Understanding Partial Least Squares Path Modeling (An introduction with R). Academic Paper Universitat Politècnica de Catalunya (UPC), Spain. 